\title{
STUDI PENERAPAN HASIL PEMBELAJARAN PENDIDIKAN PERDAMAIAN DI KOMUNITAS SEKOLAH PEREMPUAN PONDOK BAMBU, JAKARTA TIMUR
}

\author{
Karnadi \\ Program Studi Pendidikan Luar Sekoloah Universitas Negeri Jakarta \\ Email : karnadi27@gmail.com
}

\begin{abstract}
This study attempts to described the image and information about the learning education peace carried out in community school pondok bambu, women jakarta timur.pembelajaran is crucial to develop mental spiritual women in lapas women pondok bambu. The problem is the result in pondok bambu learning has been so clearly especially in building mental spiritual lapas bamboo women in this. Learning efforts are required to build higher quality who can afford to build insight, mental attitude guidance and skill residents.

Research methods that were used is research descriptive of with a qualitative approach was adopted (qualitative research) with the design of the paradigms of simple research.The determination of a small sample of uses the technique purposive dependent on whether or not the sampling method of informants as many as 20 people. The technique of the collection of data using instrument in the form of interview guidelines with informants and the third party shall to add to the data and been able to confirm their data and the direct observation of.The findings of this group of researchers from field where it has been documented learning activities education perdamain in school a female pondok bambu is activity that is performed in answer the needs will taste peace in the life of the party and participate in community events. There are positive changes show values peace happened on a community school women pondok bambu .Learning directed grow three major aspects on a community is knowledge, skill and attitude to develop the culture of peace globally. Knowledge, attitudes and skill community reflect culture and values peace is in education peace.
\end{abstract}

Keywords: The Application, Lessons, Education Peace

\begin{abstract}
Abstrak
Penelitian ini bertujuan untuk mendeskripsikan gambaran dan informasi tentang penerapan pembelajaran pendidikan perdamaian yang dilakukan di komunitas Sekolah Perempuan Pondok Bambu, Jakarta Timur.Pembelajaran merupakan hal penting untuk membangun mental spiritual perempuan di Lapas Perempuan Pondok Bambu. Masalahnya adalah hasil pembelajaran di Pondok Bambu ini masih belum begitu jelas hususnya dalam membangun mental spiritual perempuan di Lapas Bambu ini. Diperlukan upaya untuk membangun pembelajaran yang lebih berkualitas yang mampu membangun wawasan,msikap mental dan keterampilan para warga binaan.

Metode penelitian yang digunakan adalah penelitian deskriptif dengan pendekatan kualitatif (qualitative research) dengan desain penelitian paradigma sederhana. Penentuan sampel menggunakan teknik Purposive Sampling ditentukan informan sebanyak 20 orang. Tekhnik pengumpulan data menggunakan instrument berupa pedoman wawancara dengan informan dan pihak ketiga untuk menambah data dan mengkonfirmasikan data serta observasi langsung. Temuan peneliti dilapangan menunjukkan kegiatan pembelajaran pendidikan perdamain di Sekolah Perempuan Pondok Bambu merupakan kegiatan yang dilakukan dalam menjawab kebutuhan akan rasa damai dalam kehidupan berkeluarga dan bermasyarakat. Terdapat perubahan-perubahan positif yang menunjukkan nilai-nilai perdamaian yang terjadi pada komunitas Sekolah Perempuan Pondok Bambu.Pembelajaran yang diarahkan menumbuhkan tiga aspek utama pada komunitas ini yaitu pengetahuan, keterampilan dan sikap untuk mengembangkan budaya damai secara global. Pengetahun, sikap dan keterampilan komunitas mencerminkan kebudayaan dan nilai-nilai perdamaian yang ada pada pendidikan perdamaian.
\end{abstract}

Kata Kunci : Penerapan, Hasil Pembelajaran, Pendidikan Perdamaian 


\section{PENDAHULUAN}

\section{Latar Belakang Masalah}

Indonesia merupakan negara yang majemuk karena terdiri dari berbagai suku, bahasa, budaya, agama dan aliran kepercayaan. Karena keberagaman tersebut bangsa Indonesia pun rawan dengan konflik. Seperti konflik yang pernah terjadi di daerah Aceh, Poso, Ambon bahkan akhir-akhir ini sering muncul konflik sosial dan kekerasan sehingga mengancam persatuan dan eksistensi bangsa yang mengakibatkan masyarakat resah, takut, cemas, dan tak lagi merasakan suasana damai.

Rentannya bumi Indonesia akan konflik, kerusuhan, perbedaan pendapat, mobilisasi massa, kekerasan terhadap perempuan, bencana sampai kepada kebijakannya yang tidak berpihak pada rakyat, menyebabkan kerja kemanusiaan dan perdamaian menjadi penting dilakukan. Dalam hal ini peran pendidikan untuk masyarakat sangatlah diperlukan. Dalam membangunan pendidikan dimasa depan perlu dirancang sistem pendidikan yang dapat menjawab harapan dan tantangan terhadap perubahan-perubahan yang terjadi. Dalam menghadapi harapan dan tantangan

dimasa

depan, pendidikanmerupakan sesuatu yang sangat dibutuhkan dan berharga.

Pendidikan sebagai ilmu yang normatif berfungsi membawa subjek didik kearah yang lebih baik. Akan tetapi, pendidikan di Indonesia tercemar dengan ketidakmanusiaan. Contohnya seperti kekerasan dan banyaknya tawuran antar pelajar. Budaya kekerasan telah merusak jalinan persatuan sesama warga negara, yang tentu menurunkan kualitas budaya bangsa Indonesia. Dalam menjawab kebutuhan masyarakat akan rasa damai, seharusnya pemerintah menjadikan pendidikan perdamaian sebagai sebuah kurikulum yang selanjutnya dimasukan dalam kurikulum pendidikan formal.

Komunitas Sekolah Perempuan Pondok Bambu merupakan bagian dari penerapan Peace Education, karena isi materi-materi pembelajaran yang diberikan kepada komunitas ini yaitu dengan meninggalkan cara-cara kekerasan, menggunakan cara-cara nirkekerasan (anti kekerasan), melibatkan semua pihak tanpa terkecuali dan tanpa diskriminasi, membuka ruang dialog untuk mencapai kesejahteraan bersama, dan menggunakan strategi yang 
memikirkan rencana jangka pendek sekaligus juga jangka menengah dan jangka panjang. Gambaran inilah yang membuat peneliti tertarik untuk melakukan penelitian mengenai bagaimana penerapan pembelajaran pendidikan perdamaian yang ada pada komunitas ini, karena komunitas Sekolah Perempuan merupakan salah satu lingkup pendidikan luar sekolah dalam bentuk pemberdayaan pendidikan perempuan dan merupakan cakupan Pendidikan Luar Sekolah yaitu pendidikan orang dewasa yang bertujuan agar mampu mengembangkan diri secara optimal dan berpartisipasi aktif menjadi pelopor di masyarakat dalam kehidupan sosial, ekonomi, budaya yang berubah dan berkembang. Dengan melihat penerapan pembelajaran pendidikan perdamaian ini maka peneliti bisa mengetahui bahwa ternyata pendidikan perdamaian bisa menjawab kebutuhan masyarakat akan rasa damai, karena materi-materi yang diajarkan mengandung unsur anti kekerasan dan mengedapankan cinta kasih. Alasan lain yang membuat peneliti tertarik untuk menggali lebih dalam tentang permasalahan di atas adalah pertama dalam membangun perdamaian ini yang dilibatkan untuk belajar adalah kaum perempuannya yaitu ibu-ibu. Perempuan sebagai individu maupun komunitas ternyata mempunyai potensi dan kesadaran diri untuk menjadi mediator dan negosiator dalam proses perdamaian. Kedua belum banyak orang yang mengetahui pentingnya pendidikan perdamaian untuk diterapkan dalam pendidikan di Indonesia. Dengan adanya pendidikan perdamaian di komunitas ini, maka menggambarkan bahwa perempuan bisa dilibatkan dalam perdamaian sehingga konflik sosial tidak akan terus menjadi suatu ancaman yang serius bagi keutuhan dan persatuan bangsa.

\section{Rumusan Masalah}

Bagaimana gambaran penerapan pembelajaran pendidikan perdamaian di Komunitas Sekolah Perempuan Pondok Bambu, Jakarta Timur?

\section{Tujuan Penelitian}

Penelitian ini bertujuan untuk mendeskripsikan gambaran dan informasi yang tepat tentang penerapan pembelajaran pendidikan perdamaian yang dilakukan di komunitas Sekolah Perempuan Pondok Bambu, Jakarta Timur.

\section{Kerangka Berpikir}


Budaya kekerasan telah merusak jalinan persatuan sesama masyarakat, yang tentu menurunkan kualitas budaya bangsa Indonesia. Sepertinya rasa damai, aman, nyaman sudah tidak dirasakan oleh masyarakat akibat banyaknya kasus seperti tawuran, kekerasan, terorisme dan sebagainya. Dalam menjawab kebutuhan masyarakat akan rasa damai, Pendidikan perdamain bisa menjadi solusi dalam menjawab permasalahan tersebut. Pendidikan perdamaian lebih membuat peserta didik berpikir secara kritis dengan menamkan nilai-nilai perdamaian.

Nilai-nilai perdamain bisa diwujudkan apabila dilaksanakan dalam kegiatan belajar mengajar dengan materi, metode, dan model yang tepat maka hasil dari pembelajaran dapat diterapkan di kehidupan peserta didik terutama didalam keluarganya terlebih dahulu dan masyarakat sekitarnya.

Komunitas sekolah perempuan merupakan salah satu lingkup PLS yang dalam kegiatan pembelajarannya bertujuan untuk meningkatkan partisipasi perempuan dalam membangun perdamaian, maka kegiatan pembelajarannya pun mengacu pada pendidikan perdamaian. Perempuan disini dianggap mempunyai potensi dan kesadaran sebagai subjek dalam pembangunan serta menjadi mediator dan negosiator dalam mewujudkan perdamaian.

Dengan pembelajaran pendidikan perdamaian yang mereka pelajari, maka nilai-nilai perdamaian serta materi yang mereka dapatkan mampu diterapkan dalam kehidupan sehari-harinya, untuk melihat hal tersebut maka keluarga dan orang-orang sekitarlah yang merasakan apakah pendidikan perdamaian yang mereka dapatkan diterapkan dikehidupannya.

\section{KAJIAN TEORITIS}

\section{Hakikat Pendidikan Luar Sekolah}

Pendidikan luar sekolah merupakan salah satu dari tiga jenis pendidikan sebagaimana tercantum dalam Undang-Undang No.20 Tahun 2003. Suatu aktivitas dapat dikatakan sebagai pendidikan luar sekolah apabila diselenggarakan dan dibutuhkan oleh masyarakat dalam rangka mendukung pendidikan sepanjang hayat (life long education). Pendidikan luar sekolah adalah pendidikan yang dirancang untuk membelajarkan warga belajar agar mempunyai jenis keterampilan atau pengetahuan serta pengalaman yang 
dilaksanakan diluar jalur pendidikan formal (persekolahan). Pernyataan tersebut mengemukakan bahwa pendidikan luar sekolah pada dasarnya dibutuhkan atas dasar kebutuhan masyarakat atas ruang lingkup pembelajaran tertentu.

Tujuan pendidikan luar sekolah agar menciptakan individu yang mampu melihat permasalahan-permasalahan sekitar dan bertanggung jawab untuk memperbaiki kehidupannya sendiri sehingga mampu mengatasi permaslahan-permasalahan tersebut dengan memanfaatkan potensi yang ada didalam dirinya dan lingkungan sekitarnya.

\section{Hakikat Pendidikan Orang Dewasa}

Pendidikan orang dewasa adalah semua aktivitas pendidikan yang dilakukan oleh orang dewasa dalm kehidupan sehari-hari yang menggunakan sebagian waktu dan tenaganya untuk mendapatkan tambahan intelektualnya. Pendidikan orang dewasa adalah suatu usaha yang ditunjukkan untuk pengembangan diri yang dilakukan oleh individu tanpa paksaan legal, tanpa usaha menjadikan bidang utama kegiatannya.
Pembelajaran orang dewasa mencerminkan proses suatu dimana orang dewasa belajar menjadi peduli dan mengevaluasi pengalamannya. Konsep pembelajaran orang dewasa pada umumnya lebih bertujuan menemukan pengertian pengalaman atau pencarian pemikiran guna merumuskan perilaku yang standar.

\section{Hakikat Pendidikan Perdamaian}

Pendidikan dapat diartikan sebagai suatu pemberian latihan intelektual dan moral untuk menyiapkan kehidupan pada masyarakat yang akan datang. Pendidikan perdamaian diharapkan dapat membantu subjek didik memiliki keterampilan mengatasi konflik sehingga akan tercipta kehidupan yang lebih baik, aman dan damai. Keberadaan pendidikan perdamaian dalam setiap proses pembelajaran yang diperoleh masingmasing individu akan mempengaruhi sikap, karakter dan perilaku individu itu sendiri, baik pada masa sekarang maupun pada masa yang akan datang.

Pendidikan perdamaian yang didasarkan pada filosofi untuk mengajar tanpa kekerasan, penuh cinta, mengembangkan perasaan belas kasih, kepercayaan, kejujuran, keadilan, 
kerjasama dan penghormatan kepada seluruh umat manusia dan semua kehidupan di bumi ini sangat dibutuhkan untuk menciptakan kehidupan dunia yang rukun dan damai.

\section{Pendidikan}

perdamaian

merupakan salah satu upaya pembelajaran yang bisa memberikan kontribusi dan mampu menciptakan warga negara yang lebih baik di dunia ini. Cara pencapaian pendidikan perdamaian yaitu dengan menanamkan filosofi yang mendukung dan mengajar tanpa kekerasan, menjaga lingkungan dankehidupannya sendiri sebagai manusia. Pendidikan perdamaian memberikan alternatif dengan mengajarkan kepada siswa bagaimana kekerasan bisa terjadi dan menginformasikan pengetahuan kepada siswa tentang isu-isu kritis dari pendidikan perdamaian yaitu menjaga perdamaian (peacekeeping), menciptakan perdamaian (peacemaking), dan membangun perdamaian (peacebuilding).

Pendidikan Perdamaian adalah suatu proses pendidikan yang dipersiapkan untuk mengembangkan atau meningkatkan pola perilaku seseorang dalam bidang pengetahuan, keterampilan atau sikap agar mampu menciptakan kebudayaan perdamaian dan nilai-nilai perdamaian didalam kehidupan bermasyarakat dan berkeluarga.

\section{Hakikat Pembelajaran}

Pembelajaran memiliki makna yang sama dengan membelajarkan yang mengandung arti sebagai proses membuat seorang menjadi belajar. Pembelajaran adalah suatu kombinasi yang tersusun meliputi unsur-unsur manusiawi, material, fasilitas, perlengkapan dan prosedur yang saling mempengaruhi untuk mencapai tujuan pembelajaran.

Pembelajaran adalah proses yang dipelajari dalam kegiatan belajar sehingga membuat seorang menjadi belajar dalam pengembangan kreativitas berfikir yang dapat meningkatkan kemampuan berfikir warga belajar, serta dapat meningkatkan penguasaan dan pengembangan yang baik terhadap materi pembelajaran. Target belajar dapat diukur melalui perubahan sikap dan kemampuan siswa melalui proses belajar untuk mencapai tujuan yang telah direncanakan sebelumnya dan diharapkan dapat dimiliki oleh siswa serta dipraktekkan dan diterapkan 
dikehidupannya setelah mereka melakukan proses pembelajaran tersebut. Penerapan pembelajaran dapat dilakukan oleh peserta didik bila seorang tutor menggunakan strategi pembelajaran yang tepat dalam menyampikan materi pembelajaran sehingga akan memudahkan peserta didik menerima dan memahami materi pembelajaran, yang pada akhir tujuan pembelajaran dapat dikuasainya di akhir kegiatan belajar.

\section{Hakikat Komunitas}

Komunitas adalah sebuah kelompok sosial dari beberapa organisme dari berbagai lingkungan, umumnya memiliki ketertarikan yang sama. Dalam komunitas manusia, individu-individu di dalamnya dapat memiliki maksud, kepercayaan, sumber daya, preferensi, kebutuhan, risiko dan sejumlah kondisi lain yang serupa.

\section{METODOLOGI PENELITIAN}

Metode penelitian yang digunakan adalah penelitian deskriptif dengan pendekatan kualitatif (qualitative research) dengan desain penelitian paradigma sederhana. Penentuan sampel menggunakan teknik Purposive Sampling ditentukan informan sebanyak 20 orang. Tekhnik pengumpulan data menggunakan instrument berupa pedoman wawancara dengan informan dan pihak ketiga untuk menambah data dan mengkonfirmasikan data serta observasi langsung.

\section{HASIL DAN PEMBAHASAN}

Dengan adanya kegiatan pembelajaran pendidikan perdamain membuat perspektif ibu-ibu lebih memahami mengenai pendidikan perdamaian. Ibu-ibu mengetahui bahwa mencaci maki, menghina, menyakiti perasaan orang lain, bersikap emosional dan menutup akses orang lain merupakan suatu tindakan kekerasan yang sudah menghilangkan dan mengurangi sisi-sisi kemanusiaan. Dengan mengatahui hal tersebut mereka sekarang mampu mengendalikan emosi dan mengurangi tindakan kekerasan kepada anak seperti membentak, memukul, berkata kasar.

Mereka memahami bentukbentuk kekerasan, seperti memukul, mendorong, menampar merupakan bentuk kekerasan fisik. Mencaci maki, membentak, menyebut dengan sebutan yang tidak kita sukai merupakan bentuk kekerasan verbal. Bentuk kekerasan psikis seperti melarang untuk mendapatkan hak. Dengan adanya 
kegiatan pembelajaran ini mereka berjanji untuk menjadi lebih baik dalam mendidik anak-anaknya, memperlakukan suami dan keluarga lainnya, karena dampak dari kekerasan ini begitu menyakitkan korbannya.

Mereka memiliki kemampuan menejemen diri, mengungkapkan pendapat, dan berkembangkannya nalar kritis. Pola pikirnya bisa menganalisis yang lebih manusiawi dan cepat tanggap terhadap lingkungan.

Pendidikan perdamaian yang diberikan pada sekolah perempuan ini dipersiapkan untuk mengembangkan atau meningkatkan perilaku komunitas SP dalam pengetahuan, keterampilan dan kemampuan dengan mengedepankan nilai-nilai perdamaian dalam kehidupan keluarga dan bermasyarakat. Selain itu memberdayakan mereka agar mampu memecahkan konflik dengan cara-cara keatif dan bermartabat dan bukan dengan cara kekerasan.

Pembelajaran pendidikan perdamain memang sangat membawa dampak positif bagi komunitas dan lingkungannya. Pendidikan perdamain diperlukan oleh ibu-ibu sebagai suatu pemberian pengetahuan dan moral untuk menyiapkan kehidupan pada masa yang akan datang. Pendidikan perdamain yang diperoleh komunitas ini dapat membantu mereka memiliki keterampilan mengatasi konflik sosial, sehingga akan tercipta kehidupan yang lebih baik, yang aman dan damai.

Kegiatan pembelajaran yang ada pada komunitas ini merupakan kegiatan yang dilakukan untuk menjawab kebutuhan masyarakat akan rasa damai dalam kehidupan berkeluarga dan bermasyarakat. Pembelajaran yang diarahkan di SP menumbuhkan tiga aspek utama pada komunitas ini yaitu pengetahuan, keterampilan dan sikap untuk mengembangkan budaya damai secara global. Pengetahun, sikap dan keterampilan komunitas SP Pondok Bambu mencerminkan kebudayaan dan nilai-nilai perdamaian yang ada pada pendidikan perdamaian.

Mereka mengetahui dan memahami kekerasan, peduli terhadap lingkungan yang ada disekitar mereka dengan cara mengelola sampah, bentuk keadilan seperti berperan setara didalam keluarga, berani berbicara didepan umum mengenai lingkungan di wilayahnya, mampu mengendalikan emosi, tidak melakukan tindakan 
kekerasan tehadap anak, empati dan simpati terhadap tetangga jika ada yang mengalami musibah, mereka sangat menyadari perbedaan seperti kelompok agama, agama, ras, suku, pola pikirnya mampu menganalisis yang lebih manusiawi, toleransi dan saling menghargai terhadap tetangga.

\section{PENUTUP}

Pembelajaran Pendidikan perdamaian yang diarahkan di Sekolah Perempuan Pondok Bambu menumbuhkan tiga aspek utama yaitu pengetahuan, keterampilan dan sikap untuk mengembangkan budaya damai secara global. Secara pengetahuan mereka memahami mengenai toleransi dan mengetahui bahwa perdamaian merupakan hak setiap manusia, mereka memiliki keterampilan dalam mencari solusi dari permasalahan yang ada diwilayahnya (mengatasi konflik sosial) dan sikap mereka menunjukkan sikap tanpa kekerasan.

Komunitas sekolah perempuan memiliki kesadaran bahwa kekerasan hanya akan melahirkan kekerasan baru.

Penerapan Hasil pembelajaran pendidikan perdamaian di komunitas Sekolah Perempuan Pondok Bambu merupakan proses untuk mempraktekkan suatu teori atau materi yang dipelajari dalam kegiatan belajar yang diarahkan sepenuhnya untuk perkembangan kepribadian manusia dan memperkuat keperdulian terhadap hak asasi manusia, sehingga membuat seseorang mampu mengembangkan dan meningkatkan pengetahuan, sikap, dan keterampilan yang menekankan pada kebudayaan perdamaian dan nilai-nilai perdamaian dalam kehidupan berkeluarga dan bermasyarakat.

Kegiatan pembelajaran yang ada di komunitas Sekolah Perempuan (SP) ini memang bermanfaat dan sangat membawa dampak positif kepada mereka dalam menjalani dan menghadapi persoalan didalam kehidupannya sehari-hari.

Kegiatan pembelajaran pendidikan perdamaian di Sekolah Perempuan Pondok Bambu ini merupakan kegiatan yang dilakukan untuk menjawab kebutuhan akan rasa damai dalam kehidupan berkeluarga dan bermasyarakat.

\section{DAFTAR PUSTAKA}

Assegaf, Rahman Abd. 2004. Pendidikan Tanpa Kekerasan, Yogyakarta: Tiara Wacana. 
Depdikbud, 1988. Kamus Besar Bahasa Indonesia, Jakarta: Balai Pustaka.

Djohar. 2002. Pendidikan Strategik: Alternatif Untuk Pendidikan Masa Depan, Yogyakarta: LESFI.

Furchan, Arief. 2000. Pengantar Penelitian Dalam Pendidikan, Surabaya: Usaha Nasional.

Galtung, Johan, 2003. Studi Perdamaian: Perdamaian dan Konflik, Pembangunan dan Peradaban, Surabaya: Pustaka Euraka.

Handbook. 2007. Ilmu dan Aplikasi Pendidikan Bagian ke 2 Ilmu Pendidikan Praktis), Bandung: Tim Pengembang Ilmu Pendidikan FIP UPI.

Hartiningsih, Maria. 2006. Healing, Gender and Peace (Upaya Mencari Perdamaian), Jakarta: P3i NZAID.

Hosfiar, Hervy. 2008. Naskah BP3LS, Meteodelogi Belajar Orang Dewasa, Jakarta: PP3LS.

Komisi Nasional Indonesia. 2011. UNESCO dan Kebudayaan Perdamaian Memajukan Suatu Gerakan Global, Jakarta: UNESCO.

Lunandi. 1984. Andragogi, Bandung: Angkasa.
Marzuki, Saleh. 2010. Pendidikan Non Formal Dimensi Dalam Keaksaraan Fungsional Pelatihan dan Andragogi, Bandung: PT Remaja Rosdakarya.

M.B.A, Riduwan 2003. Dasar-Dasar Statistik, Bandung: Alfabeta

Malik, Oemar. 2005. Kurikulum dan Pembelajaran, Jakarta: PT Bumi Aksara.

Moleong, Lexy J. 2004. Meteodelogi Penelitian Kualitatif, Bandung: PT Remaja Rosdakarya.

Sadiman,S, Arief. 1996. Media Pendidikan, Jakarta: Rajawali Pers.

Sanjaya, Wina. 2012. Strategi Pembelajaran Berorientasi Standar Proses Pendidikan, Jakarta: Pernada.

Sudjana, H.D. 2004. Pendidikan Non Formal, Bandung: Falah Production.

Sugiyono. 2008. Metode Penelitian Pendidikan (Pendekatan Kuantitatif, Kualitatif, $R \& D$, Bandung: CV Alvabeta. Suprijanton. 2008. Pendidikan Orang Dewasa, Jakarta: Bumi Aksara. 
Jurnal Parameter Volume 30 No. 2 DOI : doi.org/10.21009/parameter.302.02

P-ISSN : 0216-261X E-ISSN : 2620-9519

Warsita, Bambang. 2008. Teknologi Pembelajaran Landasan\& Aplikasinya, Jakarta: Rineka Cipta Zainudin. 1984. Andragogi, Bandung: Angkasa.
Zuchdi, Darmiyati. 2010. Humanisasi Pendidikan: Menemukan Kembali Pendidikan Yang Manusiawi, Jakarta: Bumi Aksara. 